SOCIODEMOGRAPHIC AND SEX DETERMINANTS OF KNOWLEDGE, ATTITUDE AND PRACTICE OF WOMEN PRISONERS REGARDING THE USE OF CONDOMS

\author{
Ana Izabel Oliveira Nicolau1, Ana Karina Bezerra Pinheiro²
}

\footnotetext{
${ }^{1}$ MSc in Nursing. Assistant Professor of the Federal University of Piauí. Piauí, Brazil. E-mail: anabelpet@yahoo.com.br

${ }^{2} \mathrm{PhD}$ in Nursing. Adjunct Professor III of the Post-graduate Program in Nursing of the Federal University of Ceará. Ceará, Brazil. E-mail: ana.karina@cnpq. br
}

\begin{abstract}
This study aimed assess the knowledge, attitude and practice of women prisoners regarding the use of male and female condoms as a measure prevention of STD/HIV and their relation to sociodemographic and sexual variables. A quantitative, evaluative study type Inquiry Knowledge, Attitude and Practice, involving 155 women prisoners. Data collection was conducted from January to March 2010 in a female prison in the state of Ceará, Brazil. Only 35 women (22,6\%) had adequate knowledge about male condoms and $11(7,1 \%)$ about female condoms. Were diagnosed less favorable attitudes during oral sex. The practice proper condom had little occurrence, particularly females. The attitude was associated with the age and age of first sexual intercourse. The proper use of condoms was significantly associated with the history of prostitution. Thus, strategies to promote sexual health in the prison environment should encompass the factors complexity involved in the use of condoms.
\end{abstract}

DESCRIPTORS: Health knowledge, attitudes, practice. Prisoners. Condoms. Nursing.

\title{
CONDICIONANTES SOCIODEMOGRÁFICOS E SEXUAIS DO CONHECIMENTO, ATITUDE E PRÁTICA DE PRESIDIÁRIAS QUANTO AO USO DE PRESERVATIVOS
}

RESUMO: Objetivou-se avaliar o conhecimento, a atitude e a prática de presidiárias quanto ao uso do preservativo masculino e feminino, como medida preventiva às DSTs/HIV e suas relações com aspectos sociodemográficos e sexuais. Pesquisa quantitativa, avaliativa, do tipo Inquérito Conhecimento, Atitude e Prática, envolvendo 155 presidiárias. A coleta de dados realizou-se de janeiro a março de 2010 na penitenciária feminina do Estado do Ceará. Das mulheres investigadas, $35(22,6 \%)$ tinham conhecimento adequado sobre o preservativo masculino e $11(7,1 \%)$ sobre o feminino. As atitudes foram menos favoráveis quanto ao uso no sexo oral. A prática adequada apresentou baixa ocorrência, em especial do preservativo feminino. A atitude associou-se com a idade e a idade da coitarca, enquanto que a prática adequada associou-se com história de prostituição. Conclui-se que as estratégias de promoção da saúde sexual em ambiente prisional devem englobar a complexidade dos aspectos envolvidos no uso dos preservativos.

DESCRITORES: Conhecimentos, atitudes e prática em saúde. Prisioneiros. Preservativos. Enfermagem.

\section{CONDICIONANTES SOCIODEMOGRÁFICOS Y SEXUALES DEL CONOCIMIENTO, ACTITUDES Y PRÁCTICAS DE MUJERES RECLUSAS SOBRE EL USO DE CONDONES}

\begin{abstract}
RESUMEN: El estudio objetivó evaluar los conocimientos, actitudes y prácticas de mujeres reclusas sobre el uso de preservativos masculinos y femeninos como medida de prevención contra las ITS/VIH y sus relaciones con variables sociodemográficas e sexuales. Investigación cuantitativa, evaluativa de tipo Pesquisa Conocimientos, Actitudes y Prácticas que envolvió 155 reclusas. La recolección de datos se realizó de enero a marzo de 2010 en la cárcel de mujeres en el Estado del Ceará, Brasil. 35 mujeres (22,6\%) tenían conocimiento adecuado sobre los condones masculinos y $11(7,1 \%)$ sobre el femenino. Las actitudes fueron menos favorables durante el sexo oral. La práctica adecuada presentó poca aparición, en particular del condón femenino. La actitud se asoció con la edad y la edad de la primera relación sexual. La práctica adecuada se asoció con historia de prostitución. Por lo tanto, las estrategias para promover la salud sexual en la prisión debe abarcar la complejidad de los aspectos envueltos en el uso de condones.
\end{abstract}

DESCRIPTORES: Conocimientos, actitudes y práctica en salud. Prisioneros. Condones. Enfermería. 


\section{INTRODUCTION}

Life in prison has unique characteristics. The population deprived of liberty tends to need more healthcare, as they are at greater risks in the illness process. Therefore, health as a fundamental human right needs to be urgently included in the prison reality of the detainees in State custody.

The male is historically more associated with crime and is the predominant gender among inmates in Brazil. The participation of the woman in this prison scenario equals $5.31 \%$. However, due to their nature they tend to suffer more intensely in the prison situation, being more vulnerable to physical and psychological injuries.

The epidemiological representation of the female criminal figure tends to show a young woman, of low socioeconomic and educational levels, unemployed, a prostitute, single or separated, coming from urban areas and with low access to the healthcare services, with the majority having been arrested for drug trafficking offences. ${ }^{2}$ Coupled with this unfavorable profile, the prison system can function as a concentrator for high risk conditions for the acquisition and transmission of infections, which contributes to the high prevalence of HIV, hepatitis and Sexually Transmitted Diseases (STDs) among detainees, making them particularly vulnerable. ${ }^{3}$ However, there is little research related to the health problems of women and prevention methods in Brazilian prisons, more specifically regarding STDs/HIV, diseases more prevalent, regarding their occurrence and the adoption of risk behaviors, among prisoners than in the general population. ${ }^{4}$

Among the main risk factors that favor the spread of these diseases among women in detention are: promiscuity and sexual abuse, bi/homosexual activities, overcrowded cells, drug use, tattoos and body piercing, low use of condoms in sexual intercourse, prostitution and a history of STDs. In Brazil, the sexual route is still the main route of HIV transmission among persons deprived of liberty. ${ }^{5-6}$ The relationship between prisoners and STD/HIV, as well as being related to risk behavior, can be seen to be rooted in cultural, social and economic aspects resulting from the interaction of the women with the environment in which they live and how they comprehend it. ${ }^{4}$ The combination of all the aspects mentioned above, added to the female biological characteristics and the combination of gender inequality, stigma and discrimination, increases the vulnerability of the women deprived of their liberty to STDs/HIV.
Furthermore, they are generally from socially marginalized groups and are more likely to have been victims of gender violence or to have a history of sexual behavior without protection. ${ }^{7}$

In Brazil, unprotected sexual activity is considered the most significant risk factor for the transmission of STDs/HIV in prisons, which makes the use of condoms during sexual intercourse something essential in the prevention of STDs/HIV in the prison system. The relevance of STD/HIV prevention in prisons is emphasized in the National Plan for Prison Health (PNSSP) which advocates actions for the diagnosis, counseling and treatment of STDs/HIV, condom distribution to inmates and workers, development of educational and instructional material, provision of specific drugs, as well as actions for the diagnosis and treatment of STDs, according to the syndromic approach. ${ }^{8}$ Despite many of the planned actions being implemented by the healthcare teams of the PNSSP, including that of nursing, the nonadoption of condoms as a preventive measure is still a constant for female prisoners, whether at the time of conjugal visits, or in relationships that occurred inside the cells, in a non-legalized way. ${ }^{7-9}$ Thus, a greater emphasis on promoting the health of the woman prisoner is essential, not only due to the risks present in the prison atmosphere, but also because of the lack of preventive actions of the prison health system. The interest in developing this study arose from this overview and from the reflection on the role of nurses in spreading their practice to stigmatized populations, in this case as an active member of the PNSSP.

Given the influence of the knowledge and perception of the importance of adopting preventive health measures (attitude) in the transformation and development of personal skills for the achievement of health promotion, the importance was comprehended of evaluating the knowledge, attitude and practice of prisoners regarding the use of male and female condoms as preventive measures for STDs/HIV, as well as the relationships of these factors with sociodemographic and sexual aspects. The results indicate the diagnostic situation regarding the suitability of the three previously mentioned components and possible elucidations despite their determinants. This evaluation will provide support for the development of future policies and strategies that will facilitate the approach to STDs/HIV in a differentiated way, congruent with the singularities of the group in question. 


\section{METHOD}

This is an evaluative cross-sectional study, of the Knowledge, Attitude and Practice Survey (KAP) type, with a quantitative approach. The KAP studies belong to a category of evaluative studies, called formative evaluation, i.e. in addition to obtaining data from a specific part of the population, they identify possible pathways to more effective future interventions. They can be adapted to different contexts, aiming for the strategic planning of health promotion interventions..$^{10}$ The study scenario was a female prison in the state of Ceará. This institution, with a capacity of 300 detainees, is located in the municipality of Aquiraz-CE and is undergoing restructuring to comply with the PNSSP, already having an extensive healthcare team and adequate physical infrastructure. The study population consisted of all the women inmates of the institution during the data collection period, excluding cases of cognitive limitations that would prevent the provision of the information to be collected. By calculating for a finite population a sample of 155 women was obtained from a population size of 258 prisoners.

The data collection occurred from January to March 2010. The individual interviews were conducted in the classrooms of the school located within the prison. The participants were conveyed from the cells and workplaces within the institution to the school in groups of five by the prison officers. The initial instrument used included data regarding sociodemographic characterization. Then the KAP Survey was applied in relation to male and female condoms as methods of STDs/ HIV prevention. For this, a KAP model regarding the prevention of cervical cancer was adapted. ${ }^{11} \mathrm{In}$ this study, the knowledge, attitude and practice concerning male and female condoms as STD/HIV prevention methods were evaluated as follows:

a) Knowledge: Adequate - has heard about male and female condoms, knows that they are to prevent STDs/HIV in general and unwanted pregnancies and can cite at least three precautions necessary for the correct use of each method; Inadequate - has never heard about male or female condoms or has heard, but does not know that they are to prevent STD/HIV, or when not able to cite at least three precautions necessary for the correct use of the methods.

b) Attitude: Adequate - when the woman said that it is always necessary to use male or female condoms in all the sexual practices; In- adequate - when the woman said that using the male or female condoms is unnecessary, is not very necessary or they have no opinion about their necessity.

c) Practice: Adequate - when the woman said that she always used male or female condoms from the beginning to the end of the sexual practices performed, not having had unwanted pregnancies and not having been diagnosed with any STD since her institutionalization; Inadequate - when a woman said she does not always use male or female condoms or never uses them in the sexual practices, or even if she said she does not always use a condom from the beginning to the end of the sexual practices, and having been diagnosed with an STD since her institutionalization.

Data were compiled using the Statistical Package for the Social Sciences (SPSS) version 17.0 program and later organized as tables with absolute and relative frequencies. The sociodemographic (age, education, marital status and type of partnership) and sexual variables (age at first sexual intercourse, sexual behavior, history of prostitution, history of STD and gynecological monitoring in prison) were associated with the KAP evaluations. Pearson's Chi-square test was used to perform the statistical associations. Such associations are significant when the p value (probability) is less than or equal to $0.05 .{ }^{12}$ The ethical aspects of studies involving human beings were respected, according to Resolution No. 196 of 1996 of the National Health Council..$^{13}$ The project was approved by the Research Ethics Committee of the FUC, under protocol n. 229/09.

\section{RESULTS AND DISCUSSION}

The sociodemographic characteristics indicated a young female population, with a mean age of 29.4 years, with approximately $50 \%$ being single, and responding in court for drug trafficking offences $(82$ or $52.8 \%)$, theft ( 31 or $20 \%$ ) and robbery ( 26 or $16.7 \%)$. The data regarding the educational level revealed that more than half of the participants (88, or $56.8 \%$ ) had failed to complete Elementary Education. Furthermore, it was noted that for 115 $(74.2 \%)$ respondents the maximum educational level did not go beyond complete Elementary Education. The analysis related to the occupation before the imprisonment showed a population that performed unpaid work or held low paid jobs (maid, sales person or cleaner). Approximately 13\% had been unemployed. More than half, 87 (56.1\%) 
mentioned having had a monthly income of no more than one minimum wage. The lack of access to education, to basic survival resources, the high rates of unemployment, the underemployment, and the disruption of interpersonal relationships are some factors that may be considered in great part to be inducers of female criminality and, consequently, result in imprisonment. ${ }^{14}$

\section{Knowledge}

The evaluation of the knowledge related to the use of male condoms (MC) of the 155 participants showed that $35(22.6 \%)$ had adequate knowledge, despite all having heard about this method, which demonstrates the superficiality of the knowledge acquired. The condom and the pill are the more widespread and well known methods throughout the country, however, correct use and adequate knowledge of how to use them are not as common as the simple fact of "having heard about them". A study carried out with 472 women in Campinas-SP focused on knowledge about the use of methods, including condoms, and the reasons for the choice of method used. During the interviews the women reported a certain knowledge about the method chosen. However, in general this knowledge was based on the experience of significant people for the women and/or information that they "heard about". Often, this knowledge did not prove to be adequate, with a percentage of $47.6 \%{ }^{15}$ The evaluation of the Female Condom (FC) corroborated more unsatisfactory results, as 11 women $(7.1 \%)$ had adequate knowledge, while $138(89 \%)$ had heard about the FC. The fragility of the knowledge among the women surveyed reflects the inefficiency of how this guidance is being performed.

\section{Attitude}

The evaluation of the attitude concerning the need to always use the MC in all types of sexual practices (oral, vaginal, anal) showed adequate attitudes in $95(61.3 \%)$ of the participants. The existence of the most adequate attitude was perceived regarding the use during vaginal intercourse, as five (3.2\%) said there was little need for them, two $(1.3 \%)$ said they were unnecessary and $11(7.1 \%)$ had no opinion. The attitude was less positive in the responses regarding the opinion of the use during oral and anal sex. These practices, in turn, had the largest number of participants, 13
$(8.4 \%)$, who said that it is not necessary to use the MC, and $29(18.7 \%)$ had no opinion. Concerning the attitude towards the use of the FC, the lower perception of vulnerability in oral sex was again noted, as $73(47.1 \%)$ of the participants thought it was necessary to always use the FC during oral and vaginal practices. There was a prevalence of about $10 \%$ of participants who said the FC was not necessary during oral sex and a lack of opinion on its use when compared with vaginal intercourse. From this, an increased susceptibility may be seen regarding oral sex in relationships with men and women. It should be noted that in the homosexual context, exposure to STD/HIV occurs mainly through the manipulation of the genitals, oral sex and sharing of erotic products. Women who have sex with women are vulnerable due to contact with fluids from one another, such as menstrual blood and vaginal secretions. The possibility of Human Papillomavirus (HPV) infection and the increased risk of cervical cancer can be highlighted. Because $\mathrm{HPV}$ is a wide spread virus, with a lower frequency of homosexuals infected, practices regarded as of high incidence among them, such as oral sex, penetration with erotic products, and genital manipulation should inspire precautions. ${ }^{16}$

\section{Practice}

The investigation of the practice of condom use showed less favorable results than the previous knowledge and attitude components. This statement is based on the fact that 29 women $(18.7 \%)$ showed adequate practice with the MC, i.e. always used them in all sexual relationships, from the beginning to the end of the intercourse. The employment of the FC was even worse, in that only two $(1.3 \%)$ participants used them adequately. The difficulties encountered in adequate practice of condom use in this study are shared by another study that also involved a population deprived of liberty. The investigation in São Paulo, with 299 female detainees, inferred that the failure to use condoms in the last years, in sexual relationships with men, was reported by $95(60 \%)$ of the participants, with the others reporting irregular use. None mention regular use or their use in sex with women. ${ }^{6}$ In an Ibope study conducted with 1,298 sexually active women, the proportion of respondents who said they had tried the female condom was $2.5 \%$. Thus, from these results the lower adherence by the women investigated is clear, since two $(1.3 \%)$ used them adequately. ${ }^{17}$ 
Associations of the sociodemographic variables with the components of the KAP survey

The age variable presented a statistically significant association $(\mathrm{p} \leq 0.05)$ with the attitude component, both for the MC and the FC. The younger women presented lower percentages of adequate attitudes than those over 30 years of age. In the case of the MC, $73.8 \%$ of the 61 women from the older age group reported adequate attitudes compared to $53.2 \%$ of the 94 participants in the younger age group.

The opinions regarding the need to use the FC presented a similar finding, in that $60.7 \%$ of the 61 participants over 30 years of age possessed adequate attitudes, while $38.3 \%$ of the younger participants endorsed the need to use the FC. The adequate attitude in the older age group may be related to greater opportunities and experiences that promote the sensitization of these women. However, it was not accompanied by knowledge and encouragement to change the practice, because these two components were not associated with age, which breaks the process of developing personal skills. The data showed a higher percentage of adequate practice among the younger participants, with a difference of $9.2 \%$ when compared to older participants. A study using KAP methodology with the Brazilian population of between 15 years and 54 years of age showed that the younger population, aged 15 to 24 years, showed a lower level of knowledge regarding the forms of HIV transmission and prevention. However, concerning protected sex, it was the younger population that showed the greater use of condoms. ${ }^{18}$ Unlike the Knowledge data of the present study, the Ibope survey concluded that the indirect knowledge of condoms, at least through hearing about them, was significantly lower when the interviewees were older. ${ }^{17}$

The level of education can be directly related to the components of the KAP, especially to the knowledge. However, the results showed no significant association between the education level and the adequacy of the elements studied. The school can be configured as an important promoter space of health guidance, however, in the sample studied, although it represented an important source of information, it was not sufficient to impact directly in the knowledge, attitude and use of condoms. A more detailed analysis of this association showed that, although not significant, the prisoners with education levels greater than nine years of study presented a percentage of adequate knowledge 9.1\% greater than those with less education. Regarding the female condom, this difference was $6.9 \%$. The study of the trends in condom use between 1998 and 2005 in the Brazilian population, showed that people with a maximum of Elementary Education presented the lower proportion of use when compared with those with more education, with a proportion of approximately $22 \%$ among those who had high school or higher education. ${ }^{19}$ In a population-based study, the authors investigated 1,026 women from 20 to 60 years of age, with no significant differences found between education and condom use, as in this study. However, the study warns of the increased risk of acquiring STD/ HIV among the less advantaged both in the socioeconomic and the educational contexts. ${ }^{20}$

The hypothesis that marital status and the type of sexual partner were associated with knowledge, attitudes and practices of condom use was not confirmed in the present study. Although knowledge was higher among the women who did not cohabit with their partners, the percentage of adequate attitudes was higher among those with a companion. The practice of MC use was more adequate among those without a companion, 13 (18.9\%), as opposed to the FC, which was only used by women in marital unions. The stability of the sexual partner, as well as the marital status had no effect on the adoption of preventive measures. Despite this conclusion, it was noted that appropriate attitudes were more frequent among those with a steady partner, however, the practice prevailed among those with unstable unions, contrary to the female condom. The study of the trend of condom use between 1998 and 2005, in the Brazilian population, showed that a statistical gradient characterized the marital status, with single people presenting an increased frequency of condom use $(70.3 \%)$. A more expressive increase in condom use was also noticed among those married or with a stable partner, of $11.6 \%$ in 1998 to $25.0 \%$ in 2005. However, condom use is always higher in sexual relationships with casual partners than in those with stable ones. ${ }^{19}$

\section{Associations of the sexual variables and the components of the KAP survey}

The variables studied to identify the sexual history of the prisoners involved in the research were associated with the adequacy of the knowledge, attitudes and practices of the use of the MC and FC. The results of the association are shown in table 1. 
Table 1 - Association of sexual variables of prison inmates in Ceará with the adequacy of the KAP of the use of male and female condoms. Aquiraz-CE, 2010

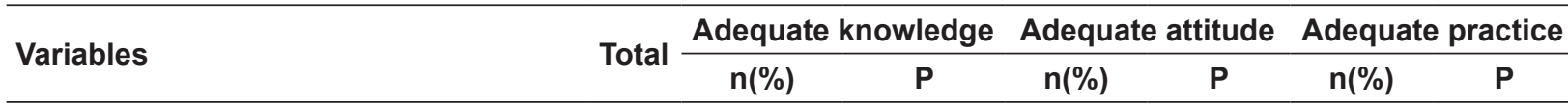

KAP male

Age of first sexual intercourse (years)

$\leq 15$

$>15$

$\begin{array}{ccccccc}106 & 22(20.8) & & 70(66.0) & & 20(18.9) \\ 49 & 13(26.2) & 0.424 & 25(51.0) & 0.050^{*} & 09(18.4) & 0.941\end{array}$

KAP female

Age of first sexual intercourse (years)

$\leq 15$

$\begin{array}{lllllll}106 & 08(7.6) & & 51(48.2) & & 01(1.0) \\ 49 & 03(6.2) & 0.748 & 22(44.9) & 0.709 & 01(2.0) & 0.574\end{array}$

$>15$

KAP male

Sexual behavior

Heterosexual

Homo/bisexual

$98 \quad 20(20.5)$

62 (63.3)

22 (22.5)

$57 \quad 15(26.4)$

0.396

$33(57.9)$

07 (12.3)

0.118

KAP female

Sexual behavior

Heterosexual

Homo/bisexual

$\begin{array}{lllllll}98 & 05(5.1) & & 51(52.1) & & 01(1.0) \\ 57 & 06(10.6) & 0.205 & 22(38.6) & 0.106 & 01(1.8) & 0.696\end{array}$

KAP male

History of prostitution

Yes

$53 \quad 16(30.2)$

37 (69.9)

$14(26.5)$

No

$10219(18.7)$

$0.102 \quad 58(56.9)$

$0.11615(14.7) \quad 0.049^{*}$

KAP female

History of prostitution

Yes

$53 \quad 05(9.5)$

25 (47.2)

$02(3.8)$

$102 \quad 06(5.9)$

0.414

$48(47.0)$

0.990

$0.048^{*}$

KAP male

History of STD

Yes

No

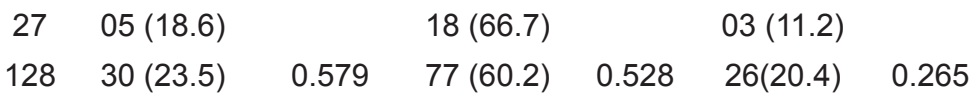

KAP female

History of STD

Yes

$27 \quad 02(7.4)$

$14(51.9)$

$128 \quad 29(7.0)$

0.945

$59(42.1)$

0.586

02(1.6)

0.513

KAP male

Gynecological monitoring in the prison

Yes

$64 \quad 17(26.6)$

$41(64.1)$

$10(15.7)$

No

$91 \quad 18(19.8)$

0.320

$54(59.4)$

$19(20.9)$

0.409

KAP female

Gynecological monitoring in the prison

\begin{tabular}{llllllll} 
Yes & 64 & $07(11.0)$ & & $32(50.0)$ & & - & \\
No & 91 & $04(4.4)$ & 0.118 & $51(45.0)$ & 0.544 & $02(2.2)$ & 0.233 \\
\hline
\end{tabular}


The early initiation of the sexual life, at 15 years of age or younger, presented a significant association with the adequate attitude regarding the use of the MC. Although this relationship did not achieve statistical significance regarding the other type of condom, once again, those who experienced first sexual intercourse younger had more appropriate opinions.

The practical component of the MC was also most consistent among those who initiated sex earliest, however, the knowledge was 5.4\% higher among those who began their sexual life after 15 years of age. Regarding the FC significant differences were not observed. Thus, those who had first sexual intercourse at 15 years of age or younger had the most adequate opinions and practices regarding the MC, however, their knowledge did not follow this trend. This result leads to a reflection on the educational opportunities and strategies in relation to the preventive measures for STDs/HIV. The fact seems certain that those who began their sexual life earlier would have greater knowledge due to the greater experience and greater use of the healthcare services, however, in reality this was not seen, which is a concern, given that effective practice should be supported by adequate knowledge.

According to a study on knowledge, attitudes and practices related to STD/HIV, condom use at first intercourse after 15 years of age increased from $53.2 \%$ in 2004 to $60.9 \%$ four years later. There was an increase from 9\% in 1986 to $60.9 \%$ in 2008, of the use of condoms at the first sexual intercourse. The lack of studies that evaluate the knowledge and attitudes about condoms in this context prevents the visualization of the differences and similarities between different populational groups. ${ }^{18}$

The analysis of the test involving the sexual behavior and KAP, although not demonstrating a significant association, showed higher percentages of adequate knowledge about the two types of condoms among the homo/bisexual women. Although they were more knowledgeable, their attitudes were less favorable than those of the heterosexual women. A total of $5.4 \%$ more of the heterosexual women presented adequate attitudes regarding the use of the $\mathrm{MC}$, and $13.5 \%$ for the FC.

The distinction between knowledge and attitude confirms the thinking of many homosexual women who do not perceive their vulnerability and, therefore, do not envision the need to use protective measures during sex. The prejudice and invisibility of this group in the educational strategies of the healthcare units in the correctional institutions, as well as in the media, constitute a barrier to changing this thinking.

In the use of the MC there was a $10.2 \%$ difference between the two sexual behavior groups, in that $22(22.5 \%)$ of the heterosexual women used the MC adequately, compared to seven (12.3\%) within the homo/bisexual group. The use of the FC did not present significant differences, despite being a method that should be more employed in sex between women.

The work of prevention of STD/HIV infection among lesbians started at the same time as the emergence of the lesbian movement in Brazil. After this initial period, the dissemination of graphic materials was begun, to their own groups, regarding the theme and the work of adapting materials for safe sex. Therefore, there is a need for the evolution of this theme, beginning with the healthcare professionals themselves. ${ }^{16}$

An ethnographic observation of homosexuality, conducted between 2003 and 2006, with 30 women aged 18 to 45 years, showed recurrent representations that associate STD to men and the attribution of a protective character or an absence of risk in the contact between women. The analysis of the perception of risks and necessary precautions associated with STDs/HIV, highlighted the notion that "AIDS cannot be passed in relationships between women" or that it is "something that we do not need to worry about". ${ }^{21}$

The chi-square test involving the history of prostitution and the adequacy of the KAP presented interesting results in terms of the use of condoms. The fact that the woman had worked in prostitution was significantly associated $(p \leq 0.05)$ with adequate practice regarding both the $\mathrm{MC}$ and the FC. Despite this not having happened with the other components of the KAP, it was perceived that knowledge of the MC was $11.5 \%$ higher, and of the FC 3.6\% higher, among those who had been prostitutes. The attitude was also more favorable, particularly regarding the need to use the $\mathrm{MC}$, presented by 37 inmates (69.9\%), which shows a difference of $13 \%$ when compared with those who had not experienced prostitution. The positive data regarding the elements of the KAP and the history of prostitution may be related to the way these women received guidance and their access to prevention support as sex workers.

In Ceará, in 1990, the Association of the Prostitutes of Ceará (APROCE) was created. The association develops educational work on sexual- 
ity and STD/HIV prevention, performs the mass distribution of the MC and FC, and encourages the use of the healthcare services for prostitutes and adolescents. An peer-driven educational model was adopted, which consists of healthcare education activities performed by prostitutes trained for this atividade. ${ }^{22}$ The social educators of the APROCE know all the prostitutes of the areas, because their registrations are made for them. They are prostitutes and former prostitutes who go to the areas to promote educational activities, to distribute condoms and receive an allowance from funded projects, donations and payment from the associates. ${ }^{23}$

In Fortaleza, a descriptive study was performed with 81 prostitutes in order to identify the sociodemographic profile and sexual behavior within this population. The results contributed to the conclusion that the use of condoms with clients was cited by all as a condition for the performance of professional sex. However, convincing the client to use one is a major challenge. On one side there is his resistance, and on the other, the fragility of the prostitute. ${ }^{24}$ Given this reality, the FC has gained importance for these women as a synonym for greater autonomy and security.

The history of STDs was not associated with knowledge, attitudes and practices of condom use. A possible weakness of this association is related to the misinformation about the types of STDs, favored by asymptomatic presentations, ignorance about the risks and difficult access to the healthcare services. The data of this relationship indicated that, although the women who reported having had an STD possessed higher percentages of appropriate attitudes, the knowledge, with the exception of the FC, and practices were more favorable in those who did not mention STDs, as was expected.

A total of $6.8 \%$ more women who had undergone gynecological monitoring inside the prison presented adequate knowledge about the $\mathrm{MC}$, and $6.6 \%$ regarding the FC, when compared to the numbers and percentages of those that had never had a gynecological consultation in the prison. The attitudes were also slightly more appropriate, by approximately $5 \%$, for the two types of preservatives.

In the institution studied the gynecology service has an equipped office in which the gynecologist and a nurse provide care. The women undergo preventive examinations within the first three months in prison, being annually invited to continue the cytological screening. The medica- tions prescribed are available in the service itself. If the inmate has any symptoms, but has not been invited, she can inform the healthcare professionals in order to be attended.

The slight differentiation is worrying, given that the gynecological consultation corresponds to one of the principle moments of conversation and guidance between professional and client regarding preventive and care measures for sexual health promotion. The relationship established during the consultation seeks to increase the knowledge on a particular theme, to instigate the transformation of opinions so that they become more favorable for later behavior changes and the adoption of healthy practices. However, the data showed a failure of this moment to achieve the objectives cited, in particular for the adoption of an adequate practice, which was more frequent, in both cases, among those who did not carry out the monitoring in the institution. Given this discussion, the analysis of the quality of the gynecological care and the evaluation of the encouragement of the use of condoms are important as part of this individual approach.

\section{CONCLUSIONS}

The sociodemographic profile of the inmates studied is the profile of many young Brazilians who live in situations of family, social and economic disintegration. The weaknesses of the public policies in ensuring quality education, housing, recreation, basic sanitation, nutrition, vocational training and work opportunities hamper the achievement of the quality of life and the increase in dignity for many people in society. The vulnerabilities of the youth articulated to a life that does not see a promising future are still catalysts of crime in the country

Regarding the knowledge about condoms, a superficiality of this component was found. If most women did not acquire sufficient knowledge about the use of preventive measures before going to prison, the health professionals, especially the nurses, should actively participate as facilitators in the teaching-learning process in health in the prison institutions. Actions that promote the sexual and reproductive health of women prisoners should not be restricted to gynecological consultations and condom distribution. The institutional spaces such as schools, workplaces, recreational areas, as well as the cells themselves, should be more utilized by the nurses for the development of educational groups grounded in 
the construction of knowledge in a participatory, dialogical and procedural way. The educational process should involve, above all, changes in attitudes. Given this premise the study diagnosed less favorable attitudes regarding the use of the FC and with reference to the employment of male and female preventive barriers during oral sex. These findings indicate situations that should be considered in the development of skills aimed at STD/HIV prevention in this group.

The adequate practice of condom use presents little representation, particularly regarding the FC, mainly due to inconsistent use. Thus, the planning of strategic actions directed towards STD/HIV prevention in female prisons should address the gender issues that make women historically vulnerable, the occurrence of homosexual relationships and the fact that they have limited knowledge about healthcare, perhaps due to a history of few educational opportunities. Regarding the association of the adequate use of condoms and the history of prostitution, it can be concluded that models similar to those of the social educators could be replicated in the prison environment, where a group of prisoners, coordinated by a nurse, could be trained to become multiplier agents of information relating to STD/HIV. Furthermore, they could provide male and/ or female condoms. Thus, barriers of access to information and preventive measures would be removed.

Given the results found, it can be perceived that the strategies to promote sexual health in the prison environment should encompass the complexity of the factors involved in the use of condoms. The strengthening of the autonomy of the individuals as the essence of the educational process, and considering the knowledge and opinions, should bring together the contexts of the environmental, social, cultural and emotional vulnerabilities.

\section{REFERENCES}

1. Ministério da Justiça (BR). Sistema Penitenciário do Brasil: dados consolidados. Informações Penitenciárias. Brasília (DF): MJ; 2008.

2. Carvalho ML, Valente JGA, Assis SG, Vasconcelos AGG. Perfil dos internos no sistema prisional do Rio de Janeiro: especificidades de gênero no processo de exclusão social. Ciênc Saúde Coletiva 2006 Abr-Jun; 11(2):461-71.

3. Araújo RC. Agência Goiana do Sistema Prisional: estudo das condições sociodemográficas e comportamentais de mulheres de detentos, relacionadas à vulnerabilidade ao vírus HIV [dissertação]. Goiânia (GO): Universidade Católica de Goiás, Programa de Pós-Graduação em Ciências Ambientais e Saúde; 2006.

4. Dorfey ES, Meneses RS, Viana JM, Oliveira GN. Infecções sexualmente transmissíveis: um estudo entre mulheres encarceradas de uma cidade do oeste baiano. Rev Digital Pesq CONQUER [Internet]. 2008 [acesso 2009 Out 15]. Disponível em: http:/ / www. fasb.edu.br/revista/index.php/conquer/article/ viewFile/89/66

5. Strazza L, Azevedo RS, Boccia TMQR, Carvalho HB. Vulnerabilidade à infecção pelo HIV entre mulheres com alto risco de exposição - menores infratoras e detentas do Estado de São Paulo, Brasil. J Bras Doenças Sex Transm. 2005 Nov; 17(2):138-42.

6. Strazza L, Massad E, Azevedo RS, Carvalho HB. Estudo de comportamento associado à infecção pelo HIV e HCV em detentas de um presídio de São Paulo, Brasil. Cad Saúde Pública 2007 Jan; 23(1):197-205.

7. Joint United Nations Programme on HIV/AIDS. A mulher e o HIV em ambientes prisionais. Vienna: United Nations; 2009.

8. Ministério da Saúde (BR). Departamento de Ações Programáticas Estratégicas. Plano Nacional de Saúde no Sistema Penitenciário. Brasília: MS; 2005.

9. World Health Organization. Interventions to address HIV in prisons: prevention of sexual transmission. Geneva: WHO; 2007.

10. Ministério da Educação (BR). Instituto Nacional do Desenvolvimento da Educação. Manual do aplicador do estudo CAP. Brasília: ME; 2002.

11. Brenna SMF, Hardy E, Zeferino LC, Namura I. Conhecimento, atitude e prática do exame de Papanicolaou em mulheres com câncer de colo uterino. Cad Saúde Pública 2001 Jul-Ago; 17(4):90914.

12. Field A. Descobrindo a estatística usando o SPSS. São Paulo (SP): Artmed; 2009.

13. Brasil. Conselho Nacional de Saúde. Resolução $n^{\circ} 196$, de 10 de outubro de 1996. Dispõe sobre diretrizes e normas regulamentadoras de pesquisas envolvendo seres humanos. Bioética 1996; 4(2 supl):15-25.

14. Priori C. Mulheres infratoras e o sistema prisional: uma discussão prévia. In: Anais do $4^{\circ}$ Congresso Internacional de História, 2009 Set 7-11; Maringá, Brasil. Maringá (PR): Programa de Pós-Graduação em História da Universidade Estadual de Maringá; 2009.

15. Espejo X, Tsunechiro MA, Osis MJD, Duarte GA, Bahamondes LG, Sousa MH. Adequação do conhecimento sobre métodos anticoncepcionais entre mulheres de Campinas, São Paulo. Rev. Saúde Pública 2003 Out; 37(5):583-90. 
16. Almeida G. Argumentos em torno da possibilidade de infecção por DST e Aids entre mulheres que se autodefinem como lésbicas. Physis 2009 Març; 19(2):301-31.

17. Paiva V, Venturi G, França Junior I, Lopes F. Uso de preservativos: pesquisa nacional MS/IBOPE. Brasília; 2003.

18. Ministério daSaúde(BR). Pesquisa deconhecimentos, atitudes e práticas relacionada às DST e Aids da população brasileira de 15 a 64 anos de idade, 2008. 2008 [acesso 2010 Jan 20]. Disponível em: http://www.aids.gov.br/pagina/pesquisa-deconhecimentos-atitudes-e-praticas-relacionadasdst-e-aids.

19. Berquó E, Barbosa RM, Lima LP. Uso do preservativo: tendências entre 1998 e 2005 na população brasileira. Rev. Saúde Pública 2008; 42(supl.1): 34-44.

20. Carreno I, Costa JSD. Uso de preservativos nas relações sexuais: estudo de base populacional. Rev.
Saúde Pública 2006 Ago; 40(4):720-6.

21. Barbosa RM, Facchini R. Acesso a cuidados relativos à saúde sexual entre mulheres que fazem sexo com mulheres em São Paulo. Cad Saúde Pública. 2009; 25(supl.2): 291-300.

22. Aquino PS. Desempenho das atividades de vida por prostitutas de Fortaleza [dissertação]. Fortaleza (CE): Universidade Federal do Ceará, Programa de Pós-Graduação em Enfermagem; 2007.

23. Moura ADA. Educação em saúde com prostitutas na prevenção das DST/Aids: reflexões à luz de Paulo Freire [dissertação]. Fortaleza (CE): Universidade Federal do Ceará. Programa de Pós-Graduação em Enfermagem; 2007.

24. Aquino OS, Nicolau AIO, Moura ERF, Pinheiro AKB. Perfil sociodemográfico e comportamento sexual de prostitutas de Fortaleza-CE. Texto Contexto Enferm. 2008 Jul-Set; 17(3):427-34. 